\title{
Hypertension in HIV-infected Patients at Boma Hospital in Democratic Republic of the Congo
}

\author{
Blaise Makoso Nimi ${ }^{1,2,5}$, Benjamin Longo Mbenza ${ }^{1,3,5}$, Carine Nkembi Nzuzi ${ }^{2,5}$, \\ Roland Vangu Vangu ${ }^{4}$, Aliocha Nkodila ${ }^{5}$, Memoria Makoso Nimi ${ }^{2}$, Antoinette Ndele Nzita ${ }^{2}$, \\ Michel Lutete Nkelani, ${ }^{1,2}$ \\ ${ }^{1}$ Department of Internal Medicine, University of Kinshasa, Democratic Republic of Congo \\ ${ }^{2}$ Department of Internal Medicine, University of President Joseph KASA-VUBU, Boma, Democratic Republic of Congo \\ ${ }^{3}$ Department of Internal Medicine, Walter Sisulu University, Mthatha, South Africa \\ ${ }^{4}$ Department of Gynecology and Obstetrics, University of Kinshasa, Kinshasa, Democratic Republic of Congo \\ ${ }^{5}$ Department of Public Health, Lomo-University Research, Kinshasa, Democratic Republic of Congo
}

Email address:

docteurmakoso@gmail.com (B. M. Nimi)

${ }^{*}$ Corresponding author

To cite this article:

Blaise Makoso Nimi, Benjamin Longo Mbenza, Carine Nkembi Nzuzi, Roland Vangu Vangu, Aliocha Nkodila, Memoria Makoso Nimi, Antoinette Ndele Nzita, Michel Lutete Nkelani. Hypertension in HIV-infected Patients at Boma Hospital in Democratic Republic of the Congo. International Journal of HIV/AIDS Prevention, Education and Behavioural Science. Vol. 7, No. 1, 2021, pp. 1-7. doi: $10.11648 / j . i j h p e b s .20210701 .11$

Received: January 18, 2021; Accepted: January 30, 2021; Published: February 9, 2021

\begin{abstract}
Background and aim: The prevalence of hypertension is steadily increasing both in the general population and in patients living with HIV. The contributing factors are from one part identical to all and other parts linked to the HIV infection and its management. Given the complications related to ART, we list the cardiovascular risk factors, determine the proportion of hypertensive in people living with HIV before treatment with ART. Methods: this was a cross-sectional study carried out from January to May 2019 at the Boma hospital located south of Kinshasa in DR Congo. It included any patient who tested positive for HIV and over 18 years of age. The parameters of interest were; demographic data, lifestyle, anthropometric and biological measurements. Results: The prevalence of hypertension was 34.5\%. Of the 115 patients with hypertension, 50 (43. $5 \%)$ knew their status and $65(56.5 \%)$ were diagnosed during the study). low CD4 count $(\mathrm{p}=0.002)$, Diabetes mellitus $(\mathrm{p}=0.001)$, advanced age $(\mathrm{p}=0.001)$ and central obesity $(\mathrm{p}=0.009)$ emerged as mainrisk factors associated with hypertension in patients with HIV. Conclusion: hypertension is one of the cardiovascular risk factors present in seropositive patients and whose prevalence should attract the attention of both political and health authorities.
\end{abstract}

Keywords: Prevalence, Hypertension, HIV Infection, Boma

\section{Introduction}

Sub-Saharan Africa (SSA) is known to be carrying the heaviest burden of HIV/AIDS in the world [1, 2] and emerging aging (epidemiologic transition), new cardiovascular risks, double burden of malnutrition (nutrition transition) [3].

In 2019, 38 million people were living with the human immunodeficiency virus (PLHIV), 26 million of them are living with SSA [4]. People living with HIV (PLWH) have an additional challenge, the emergence of chronic diseases including high blood pressure. Its prevalence continues to increase in the general population but particularly among PLWH $[5,6]$. This prevalence is also uneven, depending on the country, city and study. The result shows a higher prevalence of hypertension amongPLWH than the general population is not unanimous [7, 8]. However, the risk of developing hypertension is increased in PHAs due to HIVrelated factors such as long-term effects of antiretrovirals,hypercoagulation, atherosclerosis and systemic 
inflammatory cytotokines [8-13] without forgetting the presence of other cardiovascular risk factors known to all such as alcoholism, smoking and physical inactivity [14]. So several studies have been carried out in high-income countries on the prevalence of HTN among PLWH [15-18], data on HTN among PLWH before antiretroviral therapy in sub-Saharan Africa are still limited. The limited data available report the prevalence of hypertension in patients already on antiretroviral therapy.

In DRC prevalence of HIV infection is $1.2 \%$ [19-22], no studies have evaluated the prevalence of HTN in patients living with HIV prior to taking ARVs. However, a comparison of CVD frequency reported a prevalence of $20 \%$, $17.4 \%$ and $16.7 \%$ respectively of chronic renal failure, heart failure and stroke among PLWH.

In this study, we aim to list the cardiovascular risk factors in the group testing HIV positive before starting ART in order to better assess these factors after taking ART.

\subsection{Method}

From January 1 to December 31, 2019; We conducted a cross-sectional and descriptive study at the Boma referral hospital located in the south-east and $440 \mathrm{~km}$ from Kinshasa, the capital of DR Congo. All seropositive patients under the age of 18 who had not yet started ART treatment were included.

Socio-demographic parameters (age, sex, concept of tobacco consumption, alcohol, physical activity, level of education and socio-economic level), physical examination including blood pressure, height, weight, height and biological parameter: glycemia,creatinine, and lipid profile have been taken.

\subsection{Operational Definitions}

Hypertension was defined as blood pressure $\geq 140$ / $\geq 90 \mathrm{mmHg}$ [23].

Diabetes was defined as fasting blood glucose, $110 \mathrm{mg} / \mathrm{dl}$ or history of antidiabetic treatment [24].

Body Mass Index (BMI): computed from the height and weight of the respondent - weight divided by height squared $\left(\mathrm{Kg} / \mathrm{m}^{2}\right)$. The BMI was further classified into four categories; underweight (BMI $<18.5 \mathrm{Kg} / \mathrm{m}^{2}$ ), normal (BMI 18.5-24.99 $\mathrm{Kg} / \mathrm{m}^{2}$ ), overweight (BMI $25-29.99 \mathrm{Kg} / \mathrm{m}^{2}$ ) and obese (BMI $\geq 30 \mathrm{Kg} / \mathrm{m}^{2}$ [25]. Waist circumference (WC) was used as surrogate for abdominal obesity, defined as a $\mathrm{WC}$ value $>94$ $\mathrm{cm}$ in men and $>80 \mathrm{~cm}$ in women [26]. Smoking was defined as current use of smoked or smokeless tobacco [27]. Talking alcohol was defined as consumption of more than 1 standard drink (which is the amount of alcohol you find in a small beer, one glass of wine, or one tot of spirits per day for females and more than 2 standard drinks for males [28]. While on their usual diet, a venous blood sample wastaken from an antecubital vein for the determination of levelsof cholesterol and its sub-fractions, and triglycerides using enzymatic methods (Biomérieux France). Low-density lipoprotein cholesterol (LDL-C) was calculatedusing the Friedewald formula. [29].

\subsection{Data Analyses}

Data were analyzed using Statistical Package for the Social Sciences (SPSS) version 21 for Windows. Data were expressed as mean values \pm standard deviations (SD) for continuous variables. Frequencies (n) and percentages (\%) were reported for categorical variables. Counts (frequency $=n$ ) and percentages $(\%)$ were reported for categorical variables. Percentages were compared using the chi-square test. A pvalue of $<0.05$.

\subsection{Ethical Considerations}

The study protocol was approved by the ethics committee of the Ministry of Health. All participants provided written informed consent.

\section{Results}

Of the 333 participants, 231 (69.4\%) were Females while $102(30.6 \%)$ were males, with a sex ratio of $2.3 \mathrm{~F} / 1 \mathrm{H}$. Their mean age was $47.7 \pm 14.9$ years with $10.8 \%, 12.6 \%, 58.6 \%$ and $18.0 \%$ participants aged participants aged respectively < 20 years, $21-40$ years, $41-60$ years and $\geq 60$ years.

The proportion of unemployed, married, single, Primary/noeducation level and low SES participants was $46.7 \%, 37.9 \%, 23.9 \%, 65.0 \%$ and $59.7 \%$, respectively with a significant difference between men and women. Average levels of SBP, DBP, PP, WC BMI, blood glucose, WBC (cells $/ \mathrm{mm}^{3}$ ), Blood Creatmg/dl, CD4 and ESR were $118,0 \pm 14.5 \mathrm{mmHg}$, Total cholesterol, LDL, HDL were $75.0 \pm 14.3 \mathrm{mmHg} ; 43.0 \pm 10.4 \mathrm{mmHg}, 81.7 \pm 11.9 \mathrm{~cm}$, $23.5 \pm 4.9 \mathrm{Kg} / \mathrm{m}^{2}, 118.1 \pm 31.1 \mathrm{mg} / \mathrm{dl}, 5310.0 \pm 364.1\left(\right.$ cells $\left./ \mathrm{mm}^{3}\right)$, $3.2 \pm 1.3 \quad(\mathrm{mg} / \mathrm{dl}) \quad 307.3 \pm 188.9 \quad\left(\right.$ cells $\left./ \mathrm{mm}^{3}\right), \quad 50.8 \pm 24.8$, $174.9 \pm 48.3(\mathrm{~g} / \mathrm{dl}) \quad 116.3 \pm 44.4(\mathrm{~g} / \mathrm{dl})$ and $38.5 \pm 16.2(\mathrm{~g} / \mathrm{dl})$ respectively.

The prevalence of hypertension was $34.5 \%$. Of the 115 patients with hypertension, $50(43.5 \%)$ knew their status and $65(56.5 \%)$ were diagnosed during the study). Comparing the two groups, hypertensive people had significantly HF-DM, HF-MCV, Smoking, Physical inactivity, Menopause, Overweight, Obesity, Central obesity, n (\%) and low CD4 count. (table 2 and figure 1).

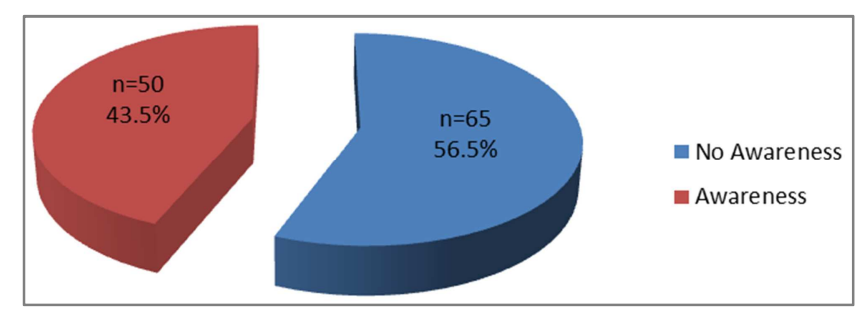

Figure 1. Frequency of awareness of $H B P$. 
Table 1. General characteristics of the study population.

\begin{tabular}{|c|c|c|c|c|}
\hline Variables & Over Alln=333 & Malen=102 & Femalen $=231$ & $\mathbf{P}$ \\
\hline Age yearsAge categories, n (\%) & $47.7 \pm 14.9$ & $48.4 \pm 12.8$ & $55.9 \pm 9.3$ & $\begin{array}{l}<0.001 \\
<0.001\end{array}$ \\
\hline$<20$ years & $36(10,8)$ & $15(14,7)$ & $21(9,1)$ & \\
\hline $21-40$ years & $42(12,6)$ & $18(17,6)$ & $24(10,4)$ & \\
\hline 41-60 years & $195(58,6)$ & $54(52,9)$ & $141(61,0)$ & \\
\hline$\geq 60$ years & $60(18,0)$ & $15(14,7)$ & $45(19,5)$ & \\
\hline Occupation, n (\%) & & & & $<0.001$ \\
\hline Businessmen & $96(26,7)$ & $45(44,1)$ & $51(22,1)$ & \\
\hline Students & $22(6,1)$ & $9(8,8)$ & $13(5,7)$ & \\
\hline Public Servants & $44(12,2)$ & $14(13,7)$ & $30(13,0)$ & \\
\hline Unemployed & $141(46,7)$ & $11(10,8)$ & $130(56,7)$ & \\
\hline Marital status, n (\%) & & & & $<0.001$ \\
\hline Married & $117(37,2)$ & $44(79,3)$ & $73(31,6)$ & \\
\hline Divorced & $74(20,6)$ & $27(4,6)$ & $47(20,3)$ & \\
\hline Single & $76(23,9)$ & $20(13,2)$ & $56(24,2)$ & \\
\hline Education level, n (\%) & & & & $<0.001$ \\
\hline Primary/no & $207(65,0)$ & $86(15.1)$ & $121(38,1)$ & \\
\hline Secondary & $108(30,0)$ & $12(54,4)$ & $96(28,8)$ & \\
\hline University/Superior & $18(5,0)$ & $4(30,5)$ & $14(4,2)$ & \\
\hline SES, n (\%) & & & & $<0.001$ \\
\hline Low & $198(59,7)$ & $32(59,1)$ & $166(49,8)$ & \\
\hline Middle & $90(27.7)$ & $48(33,9)$ & $42(12,6)$ & \\
\hline High & $45(12,6)$ & $22(7,0)$ & $23(6.9)$ & \\
\hline BMI, $\mathrm{Kg} / \mathrm{m}^{2}$ & $23.5 \pm 4.9$ & $22.2 \pm 3.6$ & $24.2 \pm 5.5$ & $<0.001$ \\
\hline $\mathrm{WC}, \mathrm{cm}$ & $81.7 \pm 11.9$ & $79.7 \pm 10.7$ & $85.4 \pm 13.2$ & $<0.001$ \\
\hline $\mathrm{SBP}, \mathrm{mmHg}$ & $118.0 \pm 14.5$ & $116.3 \pm 13.7$ & $122.4 \pm 15.6$ & $<0.001$ \\
\hline $\mathrm{DBP}, \mathrm{mmHg}$ & $75.0 \pm 14.3$ & $78,8 \pm 14.6$ & $73,5 \pm 13,9$ & $<0.001$ \\
\hline $\mathrm{PP}, \mathrm{mmHg}$ & $43.0 \pm 10.4$ & $43.5 \pm 10.3$ & $42.8 \pm 10.4$ & 0.544 \\
\hline Blood glucose, mg/dl & $118.1 \pm 31.1$ & $118.2 \pm 31.9$ & $117.9 \pm 29.7$ & 0.929 \\
\hline $\mathrm{WBC}\left(\right.$ cell $\left./ \mathrm{mm}^{3}\right)$ & $5310.0 \pm 364.1$ & $4702.9 \pm 337.3$ & $5550.0 \pm 372.0$ & 0.047 \\
\hline SGPT (UI/1) & $35.9 \pm 6.6$ & $24.3 \pm 10,9$ & $40.5 \pm 7.8$ & 0.037 \\
\hline ESR (mm/1ère hr) & $50.8 \pm 24.8$ & $49.5 \pm 23,0$ & $51.3 \pm 25.6$ & 0.556 \\
\hline Chol T (g/dl) & $174.9 \pm 48.3$ & $171.2 \pm 51,3$ & $180.9 \pm 43.1$ & 0.389 \\
\hline $\operatorname{LDL}(\mathrm{g} / \mathrm{dl})$ & $116.3 \pm 44,4$ & $115.5 \pm 48,5$ & $117.7 \pm 37.4$ & 0.827 \\
\hline HDL (g/dl) & $38.5 \pm 16.2$ & $36.2 \pm 14.9$ & $42.2 \pm 17.6$ & 0.112 \\
\hline
\end{tabular}

Table 2. Prevalence of hypertension among HIV-infected patients.

\begin{tabular}{|c|c|c|c|}
\hline CHARACTERISTICS & Yes $(n=115)$ & No $(n=218)$ & $\mathrm{p}$ \\
\hline Age $>55$ H/45 F, n (\%) & $96(83,5)$ & $208(31,7)$ & $<0,001$ \\
\hline \multicolumn{4}{|l|}{ Gender, n (\%) } \\
\hline M & $46(40)$ & $56(25,7)$ & \multirow[t]{2}{*}{0,001} \\
\hline $\mathrm{F}$ & $69(60)$ & $162(74,3)$ & \\
\hline HF-HTA, n (\%) & $29(25,2)$ & $167(25,6)$ & 0,527 \\
\hline HF-DM, n (\%) & $17(14,8)$ & $17(7,8)$ & 0,001 \\
\hline HF-Obesite, n (\%) & $3(2,6)$ & $7(3,2)$ & 0,428 \\
\hline HF- MCV, n (\%) & $16(4,3)$ & $4(1,8)$ & 0,007 \\
\hline HF-MRC, n (\%) & $1(0,9)$ & $2(0,9)$ & 0,378 \\
\hline Smoking, n (\%) & $31(27,0)$ & $41(18,8)$ & 0,002 \\
\hline Alcohol intake, n (\%) & $38(33,0)$ & $200(30,7)$ & 0,258 \\
\hline Physical inactivity, $\mathrm{n}(\%)$ & $38(33,0)$ & $46(21,1)$ & $<0,001$ \\
\hline Menopause, n (\%) & $47(40,9)$ & $36(16,5)$ & $<0,001$ \\
\hline Overweight, n (\%) & $28(24,3)$ & $36(16,5)$ & 0,001 \\
\hline Obesity, n (\%) & $18(15,7)$ & $56(8,7)$ & 0,001 \\
\hline \multicolumn{4}{|l|}{ Central obesity, n (\%) } \\
\hline CD4 count (cells/mm3) & $58(50,4)$ & $205(31,2)$ & \multirow{3}{*}{$\begin{array}{l}<0,001 \\
<0,001\end{array}$} \\
\hline$\leq 350$ & $86(74,8$ & $100(45,9)$ & \\
\hline$>350$ & $29(25,2)$ & $118(54,1)$ & \\
\hline
\end{tabular}


In univariate analysis (Table 3 ), cardiovascular risk factors significantly associated with hypertension were increased Age, Smoking, Physical inactivity, Menopause, CD4 cell (cells $/ \mathrm{mm}^{3}$ ), Overweight, Central obesity and le Diabetes mellitus. In multivariate analysis, In multivariate analysis, only advanced age, low CD4 cell count (cells / mm3), central obesity and diabetes mellitus emerged as determinants of hypertension. Indeed, the conversation of being associated with hypertension was approximately doubled in the presence of a low CD4 count (aOR 1.96; 95\% CI 1.28-3.01; $\mathrm{p}=0.002$ ) and Diabetes mellitus (aOR 2.34; 95\% CI 1.47-3.71; $\mathrm{p}=0.001$ ), it was approximately three-fold in the presence of advanced age (aOR 2.98; 95\% CI $0.5-4.35 ; \mathrm{p}=0.001$ ) and central obesity (aOR 2.68; 95\% CI 1.923.17; $\mathrm{p}=0.009$ ). (Table 3).

Table 3. Factors associated with hypertension among HIV-infected patients.

\begin{tabular}{|c|c|c|c|c|}
\hline \multirow{2}{*}{ Variables } & \multicolumn{2}{|l|}{ Analyseunivarie } & \multicolumn{2}{|c|}{ Analysemultivarie } \\
\hline & $\mathbf{p}$ & OR (IC95\%) & p & OR (IC95\%) \\
\hline \multicolumn{5}{|c|}{ Age $>55 \mathrm{H} />45 \mathrm{~F}$} \\
\hline No & & 1 & & 1 \\
\hline Yes & $<0,001$ & $4,72(3,56-6,25)$ & $<0,001$ & $2,98(2,05-4,35)$ \\
\hline \multicolumn{5}{|l|}{ Smoking, } \\
\hline No & & 1 & & 1 \\
\hline Yes & 0,002 & $1,61(1,18-2,20)$ & 0,153 & $1,34(0,90-1,99)$ \\
\hline \multicolumn{5}{|c|}{ Physical inactivity } \\
\hline No & & 1 & & 1 \\
\hline Yes & $<0,001$ & $1,87(1,39-2,50)$ & 0,121 & $1,36(0,92-1,99)$ \\
\hline \multicolumn{5}{|l|}{ Menopause } \\
\hline No & & 1 & & 1 \\
\hline Yes & $<0,001$ & $3,54(2,64-4,77)$ & 0,145 & $1,36(0,90-2,05)$ \\
\hline \multicolumn{5}{|c|}{ CD4 cell (cells/mm3) } \\
\hline & & 1 & & 1 \\
\hline$>350$ & 0,115 & $1,46(0,18-1,97)$ & 0,069 & $1,40(0,97-2,02)$ \\
\hline$\leq 350$ & 0,003 & $1,68(1,19-2,38)$ & 0,002 & $1,96(1,28-3,01)$ \\
\hline \multicolumn{5}{|l|}{ Overweight } \\
\hline No & & 1 & & 1 \\
\hline Yes & 0,001 & $1,69(1,23-2,34)$ & 0,096 & $1,90(0,17-3,06)$ \\
\hline \multicolumn{5}{|c|}{ Central Obesity } \\
\hline No & & 1 & & 1 \\
\hline Yes & 0,001 & $1,99(1,33-2,96)$ & 0,009 & $2,68(1,92-3,17)$ \\
\hline \multicolumn{5}{|c|}{ Diabetes mellitus } \\
\hline No & & 1 & & 1 \\
\hline Yes & $<0,001$ & $2,53(1,73-3,69)$ & $<0,001$ & $2,34(1,47-3,71)$ \\
\hline
\end{tabular}

\section{Discussion}

We report a prevalence of hypertension in a cohort of HIV-positive adults naïve to ART followed at the general hospital in the city ofBoma in the DRC.

The main findings of this survey are as follows. First, nearly 4 in 10 HIV-infected patients had hypertension. Second, hypertension was more common in women than in men. Third, increased age, obesity, diabetes mellitus, and CD4 count have emerged as cardiovascular risk factors specifically associated with hypertension.

The prevalence of hypertension found in the present survey is lower than that of $38 \%$ and $38.6 \%$ reported respectively in the Cameroonian study [30] and $38.6 \%$ in the South African study [31]. It is higher than that of $12.5 \%$, [32], $18 \%[33], 27.9 \%$ [34] and $19.5 \%$ and $23.7 \%$ reported in Tanzania, Senegal, Uganda and South Africa respectively and finally; this prevalence is similar to that similar have been reported in southwest Ethiopia [35]. The majority of previous studies in sub-Saharan Africa have reported a prevalence of $20-35 \%$ of HTN among PLWH [30-36].
The difference observed in our study could be due to preexisting cardiovascular risk factors, the variation in the lifestyle of the population and the size of the sample. The prevalence of hypertension among PLWH is identical to that reported in the general population in 2018 with a sample 10 times higher [37].

Older age, smoking, Smoking, Alcohol intake, Physical inactivity, MRC, HTN, DM were the most expensive cardiovascular risk factors for our patients.

The female gender predominates with a sex ratio of 2.5 this finding is reported by several African studies [29, 38].

This trend towards the feminization of HIV infection in our regions could be explained not only by anatomical vulnerability due to the fragility of the female genital mucosa and the frequent occurrence of microtrauma, financial precariousness and its consequences which expose women to financial dependence and unprotected sexual intercourse and ultimately the fact that women are screened more than men.

HIV prevalence was associated with socioeconomic level and low educational attainment. This observation is proved by many others previous studies [39, 40]. Indeed the lack of means and of employment expose to a compromising sexual behavior in the woman. Most of our 
patients were married, of which $64.7 \%$ were women. This observation is reported by other studies [38]. HIV infection thus becoming a family problem, it is common among the unemployed (46.7\%) [37]. Unemployment predisposes people to unconscious sexual behavior and especially exposes girls to HIV infection [41].

The prevalence of diabetes in this study is $13.3 \%$, it is similar to that of the general population in Africa $(2.2 \%-$ $7.0 \%$ ) [42]. A lower prevalence has been reported by many other authors $(1.8 \%$ to $2.9 \%)$ [43]. It was necessary to know this prevalence of diabetes mellitus because it is recognized that ART are involved in the development of insulin resistance and therefore of diabetes mellitus.

In the present study, women were more obese than men $20.9 \%$ vs. $17.6 \%$. This result is much lower than the $49.6 \%$ found in the general population [44]. This result is similar to that reported in Kenya [44].

Obesity could be explained not only by the stigma of people who have lost weight but also by the tendency of the community to encourage HIV patients to be obese because weight loss could easily reveal their status. Higher prevalence is reported in Africa and demonstrates the importance of insulin resistance and diabetes mellitus in this low-income environment $[45,46]$.

\section{Conclusion}

We reported a high prevalence of hypertension among PLWH in Boma. Necessary measures must be taken by the leaders, the population as well as the caregivers concerning the lifestyle, prevention and therapeutic care.

Data are expressed as mean \pm standard deviation, median (interquartile range) absolute (n) and relative (in percent) frequency. Abbreviations: $\mathrm{M}$, maleF, female SES, socioeconomic statusBMI, body mass indexWC, waist circumference SBP, systolic blood pressure DBP, diastolic blood pressure PP pulse pressure, WBC While globule, ESR sedimentation rate. In univariate analysis, advanced age, smoking, physical inactivity, gout, menopause, overweight, obesity, abdominal obesity, low CD4 count and diabetes mellitus emerged as the main ones determinants of hypertension.

\section{Author's Contribution}

BMN participated in survey conception and data collection and management; drafted the manuscript.

BLB, MMN, ANK, RPN, FNT and revised the manuscript. Benjamin B N P performed the sampling and laboratory analyzes.

\section{Conflict of Interest}

The authors declare no conflict of interest.

\section{Acknowledgements}

We thank all who participated in the study.

\section{References}

[1] Kharsany ABM and Karim QA. "HIV infection and AIDS in Sub-Saharan Africa: current status, challenges and opportunities". Open AIDS Journal 10 (2016): 34-48.

[2] Dwyer-Lindgren L., et al. "Mapping HIV prevalence in subSaharan Africa between 2000 and 2017". Nature 570.7760 (2019): 189-193.

[3] Escovitz GH. "The health transition in developing countries: a role for internists from the developed world". Annals of Internal Medicine 116.6 (1992): 499-504.

[4] World Organization. HIV/AIDS fact sheet 2016.

[5] Xu Y, Chen X, Wang K. Global prevalence of hypertension among people living with HIV: a systematic review and metaanalysis. Journal of the American Society of Hypertension. 2017; 11 (8): 530-40.

[6] Okeke NL, Davy T, Eron JJ, Napravnik S. Hypertension among HIV-infected patients in clinical care, 1996-2013. Clinical Infectious Diseases. 2016; 63 (2): 242-8.

[7] Chhoun P, Tuot S, Harries A, Kyaw N, Pal K, Mun P, et al. High prevalence of non-communicable diseases and associated risk factors amongst adults living with HIV in Cambodia. 2017 Nov 9; 12 (11): e0187591.

[8] Baekken M, Os I, Sandvik L, Oektedalen O. Hypertension in an urban HIV-positive population compared with the general population: influence of combination antiretroviral therapy. Journal of hypertension. 2008; 26 (11): 2126-33.

[9] Vecchiet J, Ucciferri C, Falasca K, Mancino P, Di Iorio A, De Caterina R. Antihypertensive and metabolic effects of telmisartan in hypertensive HIV-positive patients. Antiviral therapy. 2011; 16 (5): 639.

[10] Thie'baut R, El-Sadr WM, Friis-Moller N, Rickenbach M, Reiss P, Monforte A, et al. Predictors of hypertension and changes of blood pressure in HIV-infected patients. Antiviral therapy. 2005; 10 (7): 811.

[11] Reingold JS, Wanke C, Kotler DP, Lewis CE, Tracy R, Heymsfield S, et al. Association of HIV infection and $\mathrm{HIV} / \mathrm{HCV}$ coinfection with C-reactive protein levels: the fat redistribution and metabolic change in HIV infection (FRAM) study. Journal of acquired immune deficiency syndromes (1999). 2008; 48 (2): 142.

[12] Tien PC, Choi AI, Zolopa AR, Benson C, Scherzer R, Bacchetti $\mathrm{P}$, et al. Inflammation and mortality in HIV-infected adults: analysis of the FRAM study cohort. Journal of acquired immune deficiency syndromes (1999). 2010; 55 (3): 316.

[13] Baker J, Quick H, Hullsiek KH, Tracy R, Duprez D, Henry K, et al. Interleukin-6 and d-dimer levels are associated with vascular dysfunction in patients with untreated HIV infection. HIV medicine. 2010; 11 (9): 608-9.

[14] Deeks SG, Lewin SR, Havlir DV. The end of AIDS: HIV infection as a chronic disease. Lancet 2013; 382: 1525 \pm 33 . 
[15] Nguyen KA, Peer N, Mills EJ, Kengne AP. Burden, Determinants, and Pharmacological Management ofHypertension in HIV-Positive Patients and Populations: A Systematic Narrative Review. AIDS Rev. 2015 Apr-Jun; 17 (2): 83-95.

[16] Dillon DG, Gurdasani D, Riha J, Ekoru K, Asiki G, Mayanja BN, et al. Association of HIV and ART withcardiometabolic traits in sub-Saharan Africa: a systematic review and metaanalysis. Int J Epidemiol. 2013 Dec; 42 (6): 1754-71.

[17] Bloomfield GS, Khazanie P, Morris A, Rabadan-Diehl C, Benjamin LA, Murdoch D, et al. HIV and noncommunicablecardiovascular and pulmonary diseases in low- and middle-income countries in the ARTera: what we know and best directions for future research. Journal of acquired immune deficiency syndromes. 2014 Sep 01; 67 Suppl 1: S40-53.

[18] Nduka CU, Stranges S, Sarki AM, Kimani PK, Uthman OA. Evidence of increased blood pressure andhypertension risk among people living with HIV on antiretroviral therapy: a systematic review with metaanalysis. J Hum Hypertens. 2016 Jun; 30 (6): 355-62.

[19] Longo-Mbenza Benjamin MandinaMadone, Renzaho Andre, LepiraMbompaka François, Wumba -di-Mosi Roger et al. "Hypovitaminosis D, Aging, HIV Infection, HAART, and Other Cardiovascular Risk Factors in Patients from Kinshasa, Dr Congo, Central Africa”. EC Cardiology 6.10 (2019): 985-997.

[20] Venables E., et al. "Even if she's really sick at home, she will pretend that everything is fine: Delays in seeking care and treatment for advanced HIV disease in Kinshasa, demographic Republic of Congo". PloS One 14.2 (2019): e0211619.

[21] Vogt F., et al. "Brief report: decentralizing ART supply for stable HIV patients to community-based distribution centers: program outcomes from an urban context in Kinshasa, DRC". Journal of Acquired Immune Deficiency Syndromes 74.3 (2017): 326-331.

[22] Katchunga B, KabindaM,Matabaro M, Kashongwe M, ManyebwaJ,M'Buyamba-Kabangu JR. Séroprévalence du Virus de l'Immunodéficience Humaine parmi les admissions cardiovasculaires à l'Hôpital Provincial Général de Référence de Bukavu, RD Congo. Sidanet, 2009, 6 (9): 1211.

[23] Williams B, Mancia G, Spiering W, et al. Guidelines for the management of arterial hypertension. European Heart Journal 2018; 39 (33): 3021-104.

[24] Report of the Expert Committee on the diagnosis and classification of diabetes mellitus. Diabetes Care 2003; 26 (Suppl 1): S5-20.13.

[25] World Health Organization (WHO). The problem of overweight and obesity: preventing and managing the global epidemic. Report Series 894; Geneva, WHO, 2000: 537.

[26] Orth SR, Stockmann A, Conradt C, Ritz E, Ferro M, Kreusser $\mathrm{W}$ and al. Smoking as a risk factor for end-stage renal failure in men with primary renal disease. Kidney Int. 2008; 54: 92631 .

[27] Word Health OrganisationTWSatndrfsIW, Available at: http://www.who.int/ncds/surveillance/steps/STEPS_Manual20 17

[28] Friedewald WT, Levi RI, Fredrickson DS. Estimation of the concentration of LDL-cholesterol without use ofthe preparative ultracentrifuge. Clin Chem 1972; 18: 499-508.

[29] Duval X, Gabriel B, Daniel G, Villes V, Dupré T, Leport C et al. Living with HIV, antiretroviral treatment experience and tobacco smoking: results from a multisite cross-sectional study. AntivirTher. 2008; 13 (3): 389-397.

[30] Dimala C, Atashili J, MbuagbawJ, Wilfred A, and G. MonekossoG. Prevalence of hypertension in HIV/AIDS patients on highly active antiretroviral therapy (HAART) compared with HAARTNa"ive patients at the limbe regional hospital, Cameroon. PLoS One, vol. 11, no. 2, Article ID e0148100, 2016.

[31] Mutemwa M, Peer N, de Villiers A et al., "Prevalence, detection, treatment, and control of hypertension in human immunodeficiency virus (HIV)-infected patients attending HIV clinics in the western Cape Province, South Africa," Medicine (Baltimore), vol. 97, no. 35, Article ID e12121, 2018.

[32] Marina Njelekela,AlfaMuhihi, AkumAveika, Donna Spiegeman,Claudia Hawkins, et al. Prevalence of Hypertension and Its Associated Risk Factors among 34,111 HAART Naive HIV-Infected Adults in Dar es Salaam, Tanzania Inter J of Hypert. 2016. ID 5958382, 9 pages http://dx.doi.org/10.1155/2016/5958382.

[33] Mbaye F, NafissatouOumar T and NdeyeFatou N. Smoking in People Living with HIV (PLHA) and followed up in the Outpatient Department of the Hospital Fann of Dakar. Pamj. 2019; 34: 42.

[34] F. J. Mateen, S. Kanters, R. Kalyesubula et al., "Hypertension prevalence and Framinghamrisk score stratification in a large HIV-positive cohort in Uganda," Journal of Hypertension, vol. 31 , no. 7, pp. 1372-1378, 2013.

[35] H. Julius, D. Basu, E. Ricci et al., "e burden of metabolic diseases amongst HIV positive patients on HAARTattending the johannesburg hospital," Current HIV Research, vol. 9, no. 4, pp. 247-252, 2011.

[36] Mohammed A, YemaneShenkute T, andChenekeGebisaW, "Diabetes mellitus and risk factors in human immunodeficiency virus-infected individuals at Jimma university specialized hospital, southwest Ethiopia," Diabetes, Metabolic Syndrome and Obesity: Targets and therapy, vol. 8, pp. 197-206, 2015.

[37] Blaise MakosoNimi, François LepiraBompeka, Aliocha Nkodila, Williams Ilenga,Gédeon Long-Longo, Dieudonné Vangu Ngoma, et al. Prehypertension, Hypertension and Associated Risk Factors among Adults Living in the Port City of Boma in the Democratic Republic of the Congo. A Population-Based Cross-Sectional Survey". Acta Scientific Cancer Biology 4.5 (2020): 24-32.

[38] Coulibaly JC. Neuro-meningeal diseases during HIV infection at the infectious diseases clinic of the CHNU de Fann: prevalence and factors associated with death. Thesis Med Dakar. 201 no. 29.

[39] Dandona L, Dandona R, Kumar GA, et al. Risk factors associated with HIV in a population-based study in Andhra Pradesh state of India. Int J Epidemiol 2008; 37: 1274-86 [PubMed] [Google Scholar].

[40] Perkins JM, Khan KT, Subramanian SV. Patterns and distribution of HIV among adult men and women in India. PLoS ONE 2009; 4: e5648. 
[41] Felistas Mashinya, Marianne Alberts, Jean. Pierre Van geertruydenand Robert Colebunders. Assessment of cardiovascular risk factors in people with HIV infection treated with ART in rural South Africa: a cross sectional study. AIDS Res Ther (2015) 12: 42.

[42] Alebiosu OC, Familoni OB, Ogunsemi OO, et al. Community based diabetes risk assessment in Ogun state, Nigeria (World Diabetes Foundation project 08-321). Indian J Endocrinol Metab 2013; 17: 653.

[43] Isa SE, Oche AO, Kang'ombe AR, et al. Human Immunodeficiency Virus and Risk of Type 2 Diabetes in a Large Adult Cohort in Jos, Nigeria.
[44] BlaiseMakosoNimi, François LepiraBompeka, Gedeon Longo Longo, Benjamin Longo Mbenza, AliochaNkodila and Elysée Buanga Khuabi. Hypertension and Associated Cardiovascular Risk Factors among Adult in Boma City. Democratic Republic of the Congo. IJMSCR. 2020; 3 (4): 682-692.

[45] Gerald SB, Joseph WH, Alfred K, et al. Hypertension and obesity as cardiovascular risk factors among HIV seropositive patients in western Kenya. Plos One 2011; 6 (7): 14.

[46] Edward AO, Oladayo AA, Omolola AS, Adetiloye AA, Adedayo PA. Prevalence of traditional cardiovascular risk factors and evaluation of cardiovascular risk using three risk equations in Nigerians living with human immunodeficiency virus. N Am J Med Sci. 2013; 5 (12): 680-8. 